\title{
PENGGUNAAN GANDOS (AMPAS PATI AREN) SEBAGAI PAKAN DALAM RANSUM TERHADAP PERFORMA BABI BALI
}

\author{
DIOKSA, I M. R., I K. SUMADI, DAN I M. NURIYASA \\ Program Studi Magister Ilmu Peternakan \\ Fakultas Peternakan, Universitas Udayana, Denpasar \\ e-mail: rahmantadioksa@gmail.com
}

\begin{abstract}
ABSTRAK
Tujuan penelitian adalah untuk mengetahui pengaruh penggunaan gandos (limbah ampas pati aren) sebagai pakan sumber serat dalam ransum terhadap performa babi bali. Rancangan yang dipergunakan adalah rancangan acak lengkap (RAL) dengan empat macam perlakuan dan empat kali ulangan sehingga penelitian ini menggunakan 16 ekor babi bali jantan lepas sapih. Keempat perlakuan yang dicobakan adalah: $A=$ ransum tanpa penggunaan gandos (limbah ampas pati aren) sebagai kontrol, $\mathrm{B}=$ ransum dengan penggunaan $5 \%$ gandos, $\mathrm{C}=$ ransum dengan penggunaan $10 \%$ gandos, dan $\mathrm{D}=$ ransum dengan penggunaan $15 \%$ gandos. Variabel yang diukur dalam penelitian ini adalah berat badan awal, berat badan akhir, pertambahan berat badan (PBB), feed conversion ratio (FCR), dan konsumsi ransum.. Hasil penelitian yang telah dilaksanakan dapat disimpulkan bahwa penggunaan gandos sampai level $5 \%$ tidak mempengaruhi performa babi bali yang diberi perlakuan penggunaan gandos sebagai pakan dalam ransum.
\end{abstract}

Kata kunci: ampas pati aren, babi bali, performan

\section{USING OF GANDOS (PLAM STARCH WASTE) IN THE RATION ON THE PERFORMANCE OF BALI PIG}

\begin{abstract}
The purpose of this research is to know the influence using of gandos (palm starch waste) as source of fiber in ration to the performance of bali pig. The design used in this study was a complete randomized design (CRD) with four treatments and four replications, so 16 bali weaning piglets were used. The four treatments as of: $\mathrm{A}=$ ration without using of gandos (palm starch waste) (control), $\mathrm{B}=$ ration with $5 \%$ gandos, $\mathrm{C}=$ ration with $10 \%$ gandos, and $\mathrm{D}=$ ration with the use of $15 \%$ gandos. The variables observed in this study were initial weight, final weight, weight gain, feed conversion ratio (FCR), and feed intake. Results of the research showed that using of gandos until level $5 \%$ not affect the performance of bali pigs which were treated using gandos as feed in the ration.
\end{abstract}

Keywords: palm starch waste, bali pig, performance

\section{PENDAHULUAN}

Minat peternak memelihara babi bali sampai saat ini masih cukup tinggi karena babi bali memiliki keunggulan dapat beradaptasi dengan pola pemeliharaan yang tradisional yaitu dengan pemberian pakan yang seadanya. Selain itu, keunggulan lain babi bali adalah kemampuan mengkonsumsi limbah dapur. Babi bali juga dipakai sebagai tabungan bagi masyarakat Bali yang dikenal sebagai "tatakan banyu". Disamping itu, babi bali memiliki rasa daging yang lebih enak dibandingkan dengan babi ras (Budaarsa, 2012).
Babi bali juga memiliki kulit yang lebih empuk saat dibuat babi guling. Babi bali memiliki rasa daging yang lebih enak dan empuk dibandingkan dengan babi ras. Disisi lain kebutuhan masyarakat akan daging sebagai sumber protein hewani dari tahun ke tahun mengalami peningkatan seiring bertambahnya jumlah penduduk, pendapatan perkapita dan kesadaran masyarakat akan pentingnya bahan makanan yang bernilai gizi tinggi. Salah satu jenis daging yang dikonsumsi masyarakat di Bali adalah daging babi. Disamping babi bali digunakan sebagai babi guling untuk sesaji, di beberapa daerah tertentu ada yang masih fanatik menggunakan babi bali. 
Peternakan babi bali rakyat di Bali memanfaatkan sisa-sisa dapur, daun-daunan, batang pisang, dedak padi, dan bungkil kelapa sebagai bahan pakan ternak. Menurut Nitis (1967) dalam Sumadi et al. (2018) bahwa persentase desa yang masyarakatnya memberi pakan babi dari sisa-sisa dapur 95\%; daun-daunan $84 \%$; batang pisang $70,88 \%$; dedak padi $78,82 \%$ dan bungkil kelapa 47,64\%. Telah diketahui bahwa babi bali merupakan babi tipe lemak, tetapi sangat digemari oleh masyarakat Bali karena sangat baik jika digunakan sebagai babi guling, karena disamping rasanya enak dagingnya lembut.

Selain itu, pemanfaatan limbah pertanian sebagai pakan babi juga merupakan hal yang biasa, karena limbah-limbah hasil pertanianan dan limbah-limbah industri hasil pertanian tersebut masih kaya akan nutrisi, seperti dedak padi, bungkil kelapa, pollard, bungkil kedelai, ampas tahu, ampok jagung, dan lain sebagainya. Salah satu limbah pertanian yang memiliki nutrisi tinggi adalah limbah aren enau. Penelitian mengenai pemberian limbah ampas pati aren dari batang pohon aren enau yang ada di Bali disebut gandos sangat menarik untuk dilakukan penelitian. Di daerah pedesaan, petani sudah biasa memanfaatkan gandos sebagai pakan ternak, terutama itik dan babi. Oleh karena itu, perlu dilakukan penelitian lebih lanjut tentang penggunaan gandos (limbah ampas pati aren) sebagai pakan dalam ransum terhadap performa babi bali.

\section{MATERI DAN METODE}

Babi yang digunakan dalam penelitian ini adalah babi bali jantan lepas sapih. Rancangan yang digunakan dalam penelitian ini adalah rancangan acak lengkap (RAL) dengan empat perlakuan dan empat ulangan sehingga terdapat 16 ekor babi bali. Keempat perlakuan yang dicobakan adalah: $\mathrm{A}$ = ransum tanpa penggunaan gandos (limbah ampas pati aren) (kontrol), B = ransum dengan penggunaan gandos $5 \%, \mathrm{C}=$ ransum dengan penggunaan gandos $10 \%$ dan $\mathrm{D}=$ ransum dengan penggunaan gandos $15 \%$. Penelitian dilaksanakan di Banjar Sekarmukti, Desa Pangsan, Kecamatan Petang, Badung-Bali, Penelitian berlangsung selama dua belas minggu. Adapun variabel yang digunakan dalam penelitian ini adalah: berat badan awal, berat badan akhir, pertambahan berat badan (PBB), feed conversion ratio (FCR), dan konsumsi ransum.

Data yang diperoleh dianalisis dengan sidik ragam dan apabila terdapat perbedaan yang nyata $(\mathrm{P}<0,05)$ diantara perlakuan, maka dilanjutkan dengan uji jarak berganda dari Duncan (Steel dan Torrie, 1989) dengan menggunakan program SPSS 16.
Tabel 1. Komposisi bahan penyusun ransum penelitian

\begin{tabular}{lrrrr}
\hline \multirow{2}{*}{ Komposisi } & \multicolumn{4}{c}{ Perlakuan } \\
\cline { 2 - 5 } \multicolumn{1}{c}{ A } & \multicolumn{1}{c}{ B } & \multicolumn{1}{c}{ C } & \multicolumn{1}{c}{ D } \\
\hline Jagung kuning (\%) & 41 & 38,95 & 36,9 & 34,85 \\
Konsentrat CP 152 (\%) & 26 & 24,70 & 23,40 & 23,10 \\
Polard (\%) & 30 & 28,50 & 27,00 & 25,50 \\
Minyak sawit (\%) & 2 & 1,90 & 1,80 & 1,70 \\
Mineral 10 & 0,50 & 0,475 & 0,45 & 0,425 \\
NaCl & 0,50 & 0,475 & 0,45 & 0,425 \\
Ampas pati aren & 0 & 5 & 10 & 15 \\
Jumlah & 100 & 100 & 100 & 100 \\
\hline
\end{tabular}

\section{HASIL DAN PEMBAHASAN}

\section{Berat Badan Awal}

Hasil penelitian menunjukkan bahwa berat badan awal babi bali yang digunakan dalam penelitian ini memiliki berat badan yang tidak berbeda nyata hal ini bertujuan untuk mengetahui pengaruh dari perlakuan yang akan diberikan. Sesuai dengan pendapat Sudjana dan Ibrahim (1989) yang menyatakan bahwa pada sampling setiap individu dari populasi mempunyai peluang yang sama untuk dijadikan sampel dalam penelitian. Perhitungan berat awal sebelum diberi perlakuan dibuat signifikan atau tidak berbeda nyata agar tidak mengaburkan pengaruh perlakuan yang diberikan saat pengukuran, pada akhir penelitian, dan variasi berat badan yang didapatkan murni pada akhir penelitian dipengaruhi oleh perlakuan yang diberikan (Antari, 2015).

\section{Berat Badan Akhir}

Secara statistik perlakuan A dan B tidak berbeda nyata $(\mathrm{P}>0,05)$ tetapi perlakuan $\mathrm{A}$ berbeda nyata dengan perlakuan $\mathrm{C}$ dan D. Dengan demikian penggunaan gandos pada pakan babi bali masih baik pada level 5\%. Hasil penelitian ini menunjukkan bahwa semakin besar penggunaan gandos pada pakan babi bali maka berat badan akhir lebih rendah. Hal tersebut karena peningkatan gandos pada ransum menyebabkan rendahnya kandungan protein dan meningkatkan serat kasar sehingga penyerapan nutrisi pada tubuh ternak menjadi kurang maksimal. Menurut Wulandari et al. (2013) protein dan energi harus dipenuhi secara seimbang karena apabila kekurangan salah satu maka akan mengganggu fisiologis ternak. Kekurangan energi akan merombak protein pakan atau lemak tubuh sehingga tubuh ternak kekurangan protein. Menurut McDonald et al. (2002), rendahnya daya cerna pakan mengakibatkan banyaknya energi yang hilang dalam bentuk ekskreta sehingga nilai energi metabolis menjadi rendah. Karena semakin tinggi kadar serat kasar dalam ransum, maka dapat mengakibatkan laju pencernaan dan penyerapan nutrisi akan semakin lambat. Maka 
dari itu dengan tingginya serat kasar mengakibatkan rendahnya berat badan akhir.

\section{Pertambahan Berat Badan (PBB)}

Rata-rata persentase pertambahan bobot badan babi bali yang diberi perlakuan limbah ampas pati aren sebagai pakan dalam ransum terhadap performa babi bali menunjukkan hasil statistik yang tidak berbeda nyata $(\mathrm{P}>0,05)$.

Tabel 2. Pengunaan gandos (limbah ampas pati aren) sebagai pakan dalam ransum terhadap performa babi bali

\begin{tabular}{lrrrrr}
\hline \multirow{2}{*}{ Variabel } & \multicolumn{5}{c}{ Perlakuan $^{1)}$} \\
\cline { 2 - 5 } & \multicolumn{1}{c}{$\mathrm{A}$} & $\mathrm{B}$ & \multicolumn{1}{c}{$\mathrm{C}$} & $\mathrm{D}$ & SEM $^{2}$ ) \\
\hline Berat badan awal (kg) & $\left.11,68^{\mathrm{a}}\right)$ & $11,40^{\mathrm{a}}$ & $11,58^{\mathrm{a}}$ & $11,40^{\mathrm{a}}$ & 0,58 \\
Berat badan akhir (kg) & $40,54^{\mathrm{c}}$ & $39,92^{\mathrm{bc}}$ & $38,84^{\mathrm{ab}}$ & $37,88^{\mathrm{a}}$ & 0,43 \\
Pertambahan berat & $28,48^{\mathrm{b}}$ & $27,68^{\mathrm{ab}}$ & $26,58^{\mathrm{ab}}$ & $25,47^{\mathrm{a}}$ & 0,72 \\
badan (kg) & & & & & \\
Konsumsi ransum (kg/h) & $1,16^{\mathrm{a}}$ & $1,19^{\mathrm{b}}$ & $1,20^{\mathrm{b}}$ & $1,20^{\mathrm{b}}$ & 0,01 \\
FCR & $3,38^{\mathrm{a}}$ & $3,53^{\mathrm{a}}$ & $3,84^{\mathrm{a}}$ & $3,86^{\mathrm{b}}$ & 0,12 \\
\hline
\end{tabular}

Keterangan:

1) $\mathrm{A}=$ ransum tanpa penggunaan gandos (ampas pati aren) (kontrol); $\mathrm{B}=$ ransum dengan penggunaan $5 \%$ gandos (ampas pati aren); $C=$ ransum dengan penggunaan $10 \%$ gandos (ampas pati aren); $\mathrm{D}=$ ransum dengan penggunaan $15 \%$ gandos (ampas pati aren)

2) $\mathrm{SEM}=$ Standard Error of Treatmet Means

3) Nilai dengan superskrip yang sama pada baris yang sama menunjukkan perbedaan yang tidak nyata $(P>0,05)$

Hasil penelitian menunjukkan bahwa semakin banyak penggunaan gandos dalam ransum maka semakin rendah pertambahan berat badan babi. Gandos merupakan limbah yang mengandung sumber serat, semakin tinggi kandungan serat dalam ransum maka akan mempengaruhi daya cerna dan konsumsi ransum serta sekaligus mempengaruhi efisiensi penggunaan ransum sehingga pertambahan berat badan babi bali lebih rendah pada babi yang diberi ransum dengan kandungan gandos lebih banyak. Hal ini sejalan dengan pernyataan Crampton dan Harris dikutip Sinaga (2010) yang menyebutkan bahwa ransum yang dikonsumsi ternak mempengaruhi tinggi rendahnya pertambahan berat badan pada ternak. Menurut Ariana (2012) pertambahan berat badan ternak dipengaruhi oleh kondisi ternak yang tidak dapat mengatasi cekaman yang terjadi sehingga meningkatkan penggunan sumber energi. Degradasi sumber glikogen terjadi melalui glikolisis dengan tujuan memenuhi kebutuhan energi untuk jaringan dan sel-sel tubuh. Oleh karena itu, kandungan energi dalam ransum sangat mempengaruhi pertambahan berat badan ternak.

\section{Konsumsi Ransum}

Hasil penelitian menunjukkan bahwa penggunaan gandos meningkatkan serat kasar pada pakan hal ini menyebabkan babi meningkatkan konsumsinya, pernyatan tersebut didukung oleh Wahju (2004) yang menyatakan bahwa bahan-bahan makanan yang mengandung serat kasar yang tinggi mempunyai nilai energi yang rendah dan sebaliknya. Hal ini akan mendorong babi mengkonsumsi ransum yang lebih banyak. Konsumsi ransum yang meningkat belum mampu meningkatkan pertumbuhan, terbukti ratarata persentase pertambahan bobot badan babi bali yang diberi perlakuan limbah ampas pati aren yang meningkat dalam ransum menunjukan performa yang tidak berbeda nyata $(\mathrm{P}>0,05)$. Bila kandungan energi dalam pakan yang dikonsumsi tidak sesuai dengan kebutuhan, maka konsumsi pakan akan tinggi sedangkan jika kebutuhan energi melebihi yang diperlukan maka konsumsi pakan sebaliknya akan berkurang. Lebih lanjut Natsir (2004) menyatakan bahwa bahan pakan yang mengandung serat kasar rendah akan lebih mudah dicerna yang akan mengakibatkan energi metabolisme yang tinggi sehingga konsumsi pakan sejalan dengan kandungan serat kasar pada pakan.

\section{FCR}

Penelitian menunjukkan bahwa semakin tinggi kandungan gandos dalam ransum semakin tinggi pula FCR dari ternak babi tersebut. Pada perlakuan A, B, dan $\mathrm{C}$ menunjukkan hasil yang tidak berbeda nyata sedangkan perlakuan D menunjukkan perbedaan yang nyata $(\mathrm{P}<0.05)$. Berdasarkan data tersebut maka penambahangandos sebagai sumber serat dalam ransum sebaiknya dibatasi pada 10\%. Hasil secara statistik, rata-rata berat badan akhir babi bali menunjukkan hasil yang berbeda nyata $(\mathrm{P}<0,05)$. Anggorodi (1985) menyatakan bahwa faktor-faktor yang mempengaruhi feed convertion ratio (FCR) yaitu suhu, laju perjalanan makanan dalam organ pencernaan, bentuk fisik bahan pakan, komposisi ransum, dan pengaruh perbandingan dari zat-zat makanan lainnya. Hal ini dilihat juga dari konsumsi ransum yang menunjukkan bahwa dengan semakin tinggi penggunaan gandos dalam ransum maka konsumsi ransum semakin meningkat namun pertambahan berat badan menunjukkan sebaliknya sehingga FCR menunjukkan hasil bahwa perlakuan D memiliki nilai FCR lebih tinggi.

\section{SIMPULAN}

Dari hasil penelitian yang telah dilaksanakan dapat disimpulkan bahwa penggunaan limbah ampas pati aren (gandos) di atas 5\% dalam ransum berpengaruh negatif terhadap performa babi bali terutama pertambahan berat badan lebih rendah dibandingkan dengan tanpa gandos. 


\section{DAFTAR PUSTAKA}

Anggorodi, R.1985. Kemajuan Mutakhir Ilmu Makanan Ternak Unggas. Cetakan Pertama. Universitas Indonesia Press. Jakarta.

Antari, L. Y. S., I N. T. Ariana, dan N. W. Siti. 2015. Pengaruh penambahan probiotik starbio dalam ransum komersial terhadap produksi ayam broiler. Journal of Tropical Animal Science. Vol. 3 No. 2 Th. 2015: 259-270.

Ariana, I N.T. 2012. Pengaruh Penanganan Sebelum Pemotongan terhadap Produksi dan Kualitas Karkas Babi Landrace Persilangan. Disertasi. Universitas Udayana.

Budaarsa, K. 2012. Babi Guling Bali, Dari Beternak, Kuliner Hingga Sesaji. Penerbit Buku Arti. Denpasar.

McDonald. P, Edwards R. A, Greenhalga J. F. D, and Morgan C. A. 2002. Animal Nutrition. $6^{\text {th }} \mathrm{Ed}$.

Natsir, M. H. 2004. Nilai energi metabolis dan kecernaan protein tiga bahan pakan lokal pada ayam ras. JIIP 14 (1): 42-54 ISSN: 085213581.
Sinaga, S. 2010. Peternakan Babi Kreman di Kretek Wonosobo. Artikel. http://unpad.ac.id/SaulandSinaga. (Diakses tanggal 5 Januari 2016).

Steel, R. G. D. dan J. H Torrie. 1989. Prinsip dan Prosedur Statistika. Penerbit PT Gramedia, Jakarta.

Sudjana, N. dan Ibrahim. 1989. Penelitian dan Penilaian Pendidikan. Sinar Baru. Bandung.

Sumadi I.K., I M Suasta , I P . Ari Astawa, A. A. P. P . Wibawa, dan A. W. Puger. 2018. Pengaruh penambahan campuran asam amino esensial dan kolin (aminovit) dalam pakan tradisional terhadap penampilan babi bali jantan. Majalah Ilmiah Peternakan. Volume 21 Nomor 1 Februari 2018.

Wahju, J. 2004. Ilmu Nutrisi Unggas. Gadjah Mada University Press. Yogyakarta.

Wulandari, K. Y., V. D. Y. B. Ismadi, dan Tristiarti. 2013. Kecernaan serat kasar dan energi metabolis pada ayam kedu umur 24 minggu yang diberi ransum dengan berbagai level protein kasar dan serat kasar. Animal Agriculture Journal, Vol. 2. No. 1, 2013, p 9-17. 